\title{
Multiple Controls by Adenosine Receptors on the Adenylate Cyclase in the Rat Hepatic Membrane
}

\author{
Sumio SHIMA and Nobu AKAMATU \\ Department of Biochemistry. St. Marianna University School of Medicine, \\ 2-16-1 Sugao. Miyamae-ku, Kawasaki, Kanagawa 213, Japan \\ Accepted April 26, 1990
}

\begin{abstract}
The effects of an adenosine analog. $N^{6}$-phenyl-isopropyl-adenosine $(P \mid A)$, on the glucagon-stimulated adenylate cyclase activity in rat hepatic membranes were studied. Adenosine at high concentrations $(>10 \mu \mathrm{M})$ has been reported exclusively to inhibit the adenylate cyclase via intracellular P-sites of the hepatic membrane. The stimulation by glucagon of the enzyme was attenuated by nanomolar concentrations of PIA in the presence of low concentrations $(<1.0 \mu \mathrm{M})$ of GTP, indicating the effect of the guanine nucleotide inhibitory system (Ni). This inhibition by PIA required the presence of sodium chloride and was antagonized with isobutyl methylxanthine, an antagonist for the extracellular R-site receptors. The inhibitory effects of PIA disappeared and reversed into a stimulatory phase with increasing concentrations of GTP, suggesting the presence of a stimulatory (Ns) and an inhibitory ( $\mathrm{Ni}$ ) guanine nucleotide system of the enzyme in the action of the adenosine. PIA concentrations over a micromolar were observed to stimulate the enzyme activity in a GTP-dependent manner, indicating the presence of the stimulatory receptor $\left(A_{2}\right.$ or $\mathrm{Ra}$ ) coupled to the $\mathrm{Ns}$. These results suggest that receptors for adenosine of the inhibitory type $\left(A_{1}\right.$ or $\left.R i\right)$ and the stimulatory type $\left(A_{2}\right.$ or $R a$ ) are present on the rat hepatic membrane, showing multiple controls of the adenylate cyclase system, depending on the cellular concentrations of GTP and/or sodium chloride.
\end{abstract}

Adenosine has been reported to regulate adenylate cyclase with stimulatory and/or inhibitory effects in many tissue systems (1). The effects of nanomolar concentrations of adenosine are reported to be mediated through extra-cellular $\mathrm{R}$-sites requiring integrity of the ribose ring, but modifications on the purine ring subdivided the receptor sites into stimulatory $\left(A_{2}\right.$ or $\left.R a\right)$ and inhibitory ones $\left(A_{1}\right.$ or $\left.\mathrm{Ri}\right)(2,3)$. The effects of higher than micromolar concentrations of adenosine appear to be mediated via intracellular Psites with an intact purine moiety, but modification of the ribose moiety of the molecule caused it to be inhibitory towards the enzyme $(1,4)$. Studies on adrenal tumor cells $(5,6)$ and bone cells ( 7 ) indicate that relatively high concentrations $(>10 / \mathrm{M})$ of adenosine and related nucleosides stimulate adenylate cyclase activity. On the contrary, Glynn and
Cooper (8) and Shima (9) have reported an inhibitory action of adenosine on the ACTHstimulated adenylate cyclase activity of adrenocortical membranes.

In hepatic membranes, adenosine has been reported exclusively to inhibit the adenylate cyclase system (10.11). This inhibition, however, was apparent in the presence of relatively high concentration $(>10 \mu \mathrm{M})$ of adenosine $(10,11)$, indicating that the effect was mediated via intracellular $P$ sites $(1,4)$.

On the contrary, stimulation of the adenylate cyclase-cyclic AMP system by adenosine agonists for extracellular R-sites has been observed in the hepatic membrane ( 3 . 12-14).

The purpose of this investigation was to examine the precise mechanism of these dual effects of adenosine on extracellular R-sites of the adenylate cyclase moiety in the rat 
hepatic membrane.

\section{Materials and Methods}

Cyclic AMP was generously donated by Daiichi Selyaku. Tokyo, Japan. Glucagon was obtained from Calbiochim-Hoechst, Tokyo, Japan. (+)-N $\mathrm{N}^{6}$-phenylisopropyl-adenosine (PIA) and 3-methyl-1-isobutylxanthine (IBMX) were from Boehringer-Mannheim. F.R.G. and Aldrich Chemical Co., Milwaukee. Wl, respectively.

Preparation of hepatic membranes: Male rats of the Donryu strain (Nippon Rats Co. Ltd., Tokyo, Japan), weighing between 180 and $200 \mathrm{~g}$, were used. After the liver had been perfused to remove blood, pieces of approx. $2.0 \mathrm{~g}$ were removed to the homogenization medium containing $154 \mathrm{mM} \mathrm{NaCl}, 20 \mathrm{mM}$ sodium-Hepes ( $\mathrm{pH} 7.5$ ). Plasma membranes obtained from the procedure of Neville (15) up to step 11 were suspended in 10 volumes of $10 \mathrm{mM}$ sodium-Hepes $(\mathrm{pH} 7.5), 1 \mathrm{mM}$ mercapto-ethanol, centrifuged at $24,000 \times \mathrm{g}$ for $10 \mathrm{~min}$ at $4^{\circ} \mathrm{C}$, washed three times, and dialyzed for $2 \mathrm{hr}$ in the cold buffer containing $0.01 \%$ activated charcoal to remove endogenous adenosine associated with the membranes. Membrane protein was determined by the method of Lowry et al. (16).

Adenylate cyclase assays: Adenylate cyclase activity was estimated by incubation of the membranes in $40 \mathrm{mM}$ Tris- $\mathrm{HCl}$ buffer $(\mathrm{pH}$ 7.4), containing $4 \mathrm{mM} \mathrm{MgCl} 2.5 \mathrm{mM}$ theophylline, $2 \mathrm{mM}$ ATP, $100 \mu \mathrm{g} / \mathrm{ml}$ pyruvate kinase, and $5 \mathrm{mM}$ phosphoenolpyruvate for $10 \mathrm{~min}$, as previously described (17-19). Cyclic AMP formed during incubation was estimated by a competitive binding assay (20), using a protein purified from rabbit skeletal muscle through the DEAE-cellulose column step.

\section{Results}

Hepatic adenylate cyclase activity from male adult rats was responsive to increasing concentrations of glucagon in the presence of $1 \mu \mathrm{M} \mathrm{GTP} \mathrm{(Fig.} \mathrm{1).} \mathrm{As} \mathrm{shown} \mathrm{in} \mathrm{Fig.} \mathrm{2,}$ stimulation by glucagon of adenylate cyclase activity was GTP-dependent. Figs. 3 and 4 present the activation of adenylate cyclase by PIA with regard to GTP-dependency. The concentration of PIA required for half-maxi-

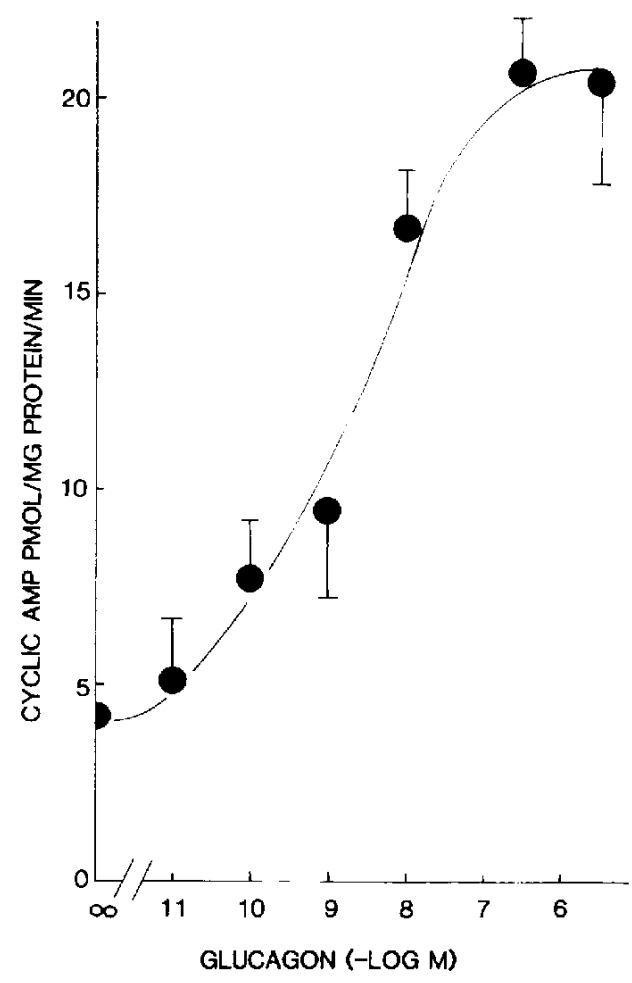

Fig. 1. Effects of glucagon on hepatic adenylate cyclase activity in the presence of $1 \mu \mathrm{M}$ GTP. Adenylate cyclase was assayed as described under Materials and Methods. The incubation with various concentrations of glucagon was carried out for 10 min. Results shown are the means \pm S.E. of four incubations.

mal stimulation (ED50) was approximately $1.0 \mu \mathrm{M}$ (Fig. 3). Concentrations of GTP required for half-maximal stimulation (ED50) were in the range of $0.1 \mu \mathrm{M}$ (Fig. 4). The stimulation by $10 \mathrm{nM}$ glucagon of adenylate cyclase activity was attenuated by $\mathrm{PIA}$ in a dose-dependent manner (Fig. 5). The concentration resulting in half-maximum inhibition (IC50) of PIA was in the range of nanomolar concentrations. This inhibition by PIA absolutely required the presence of 200 $\mathrm{mM}$ sodium chloride.

In the absence of added GTP, there was no inhibition of the glucagon-stimulated enzyme by PIA (Fig. 6). Figure 6 demonstrates the GTP-dependent process for the inhibitory action of PIA on the glucagon-stimulated activity at micromolar concentrations of the 
nucleotide. GTP over $10 /$ M exclusively manifested a stimulation by glucagon (Fig. $6)$.

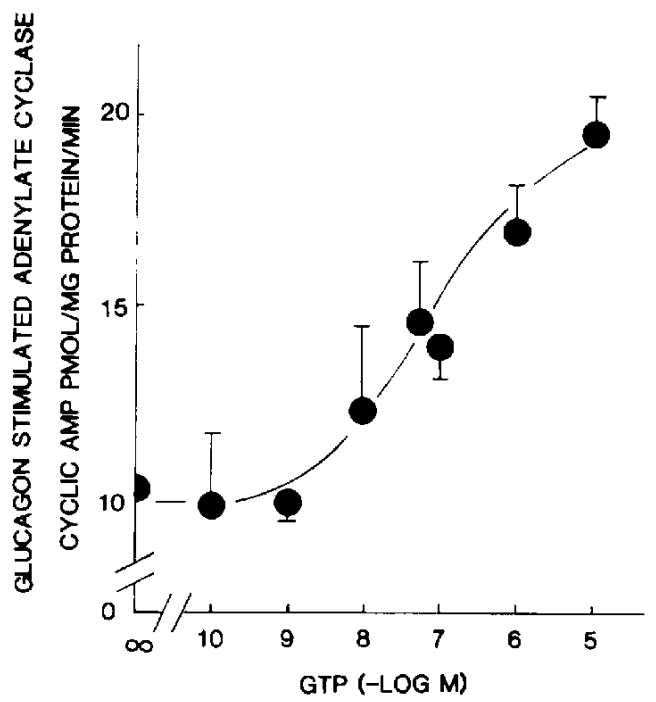

Fig. 2. GTP-dependent stimulation of glucagonactivated adenylate cyclase activity in hepatic membranes. Membranes were incubated with increasing concentrations of GTP in the presence of $10 \mathrm{nM}$ glucagon. MeanstS.E. of four incubations are shown.

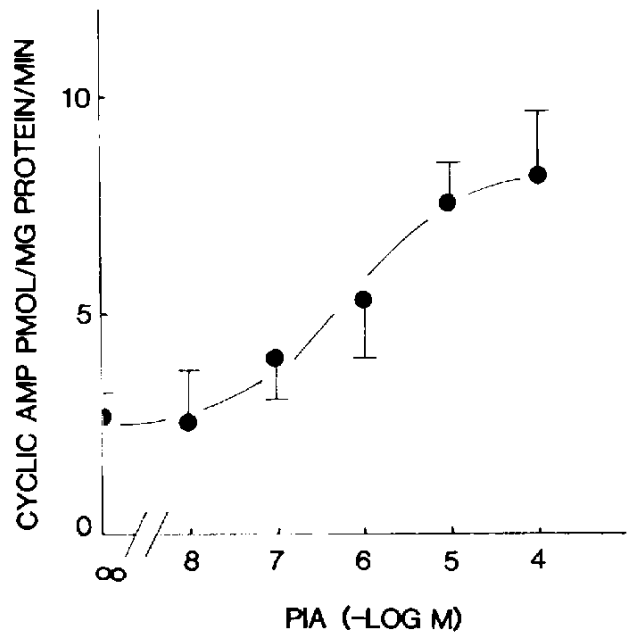

Fig. 3. Effects of $N^{6}$-phenylisopropyladenosine (PIA) on adenylate cyclase activity in hepatic membranes. Adenylate cyclase activity in the presence of $1 / \mu \mathrm{M}$ GTP was assayed with increasing concentrations of PIA. Results shown are the means $\pm S . E$. of triplicate incubations.

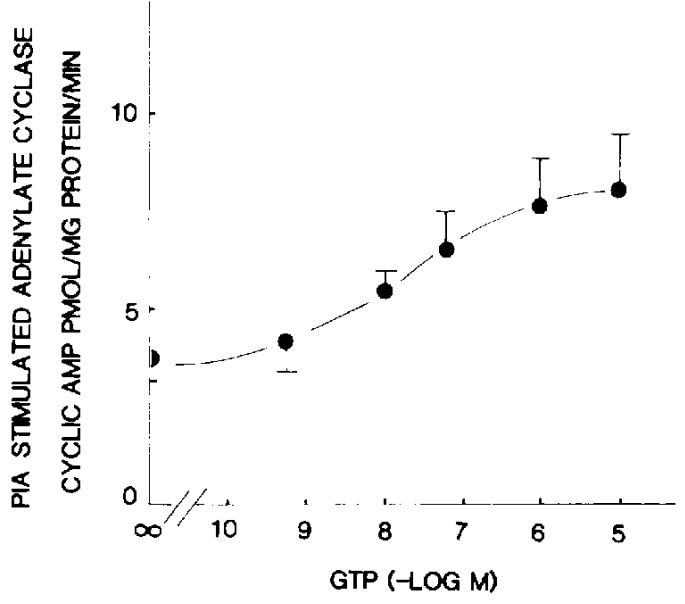

Fig. 4. GTP-dependent stimulation of $N^{6}$-phenylisopropyladenosine (PIA)-activated adenylate cyclase activity in hepatic membranes. Membranes were incubated with increasing concentrations of GTP in the presence of $10 \mu \mathrm{M}$ PIA. Means \pm S.E. of triplicate incubations are shown.

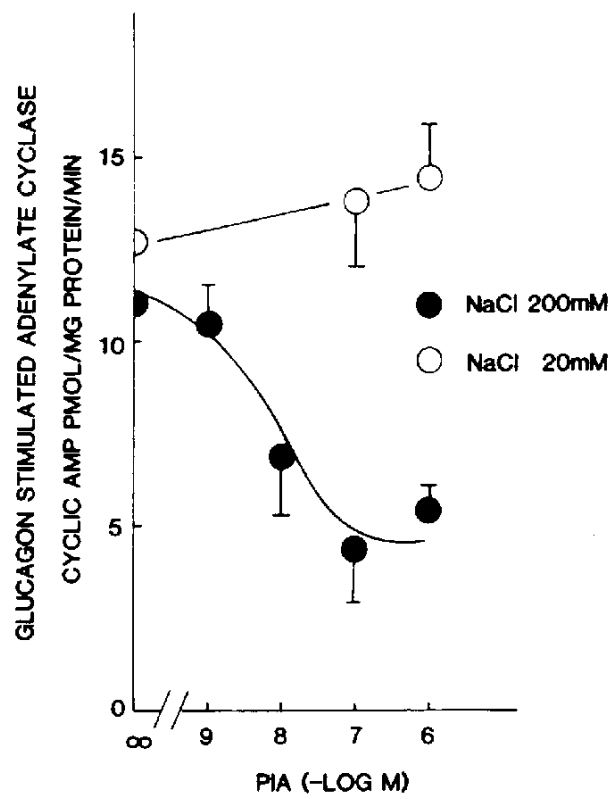

Fig. 5. Effects of sodium chloride on inhibition of giucagon-stimulated adenylate cyclase activity by $N^{6}$-phenylisopropyladenosine (PIA) in hepatic membranes. Membranes were incubated with the indicated concentrations of sodium chloride in the presence of $10 \mathrm{nM}$ glucagon and $1 \mu \mathrm{M}$ GTP. Values shown represent the means $\pm S$.E. of triplicate incubations. 


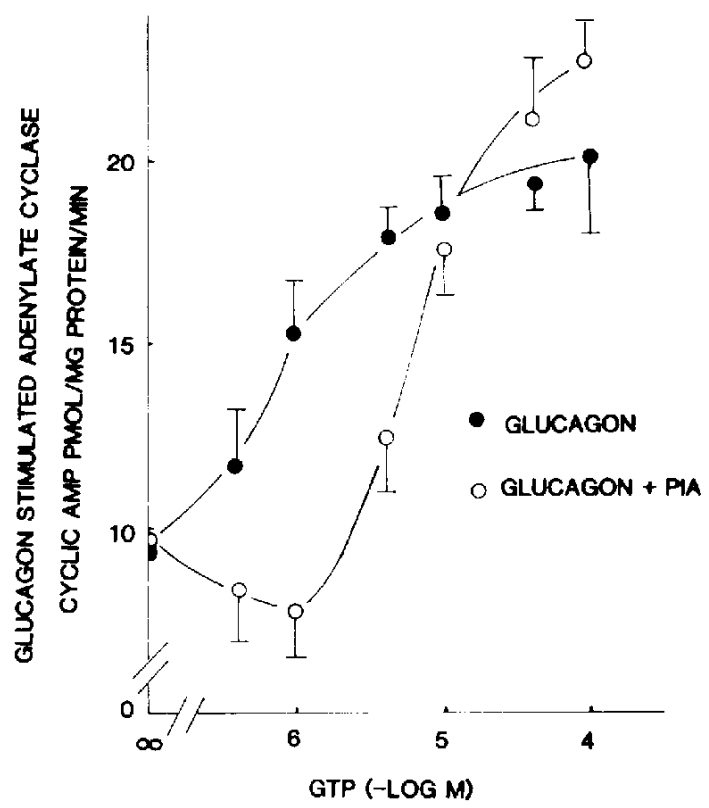

Fig. 6. GTP-dependent inhibition of glucagonstimulated adenylate cyclase activity by $N^{6}$ phenylisopropyladenosine (PIA) in hepatic membranes. Incubations with various concentrations of GTP were made with $10 \mathrm{nM}$ glucagon and $200 \mathrm{mM}$ $\mathrm{NaCl}$ in the presence or absence of $0.1 \mu \mathrm{M}$ PIA. Values shown represent the means $\pm S$.E. of triplicate incubations.

The inhibition by PIA of the glucagonstimulated enzyme was evident in the presence of $200 \mathrm{mM}$ of sodium chloride and clearly antagonized with $0.1 \mathrm{mM}$ IBMX (Fig. 7).

\section{Discussion}

Relatively large doses of adenosine (20 $\not \mathrm{M})$ have been reported to inhibit adenylate cyclase activity in hepatic membranes (10. $11,21-24)$, suggesting that the inhibition was mediated via intracellular P-sites requiring an intact purine moiety, while modifications in the ribose portion had no effect on this action (1,4). An increase in cellular cyclic AMP in the response to pharmacological concentrations $(10 \mu \mathrm{M})$ of adenosine and an $A_{2}$ (or Ra) agonist such as 2-chloroadenosine has been reported in isolated rat hepatocytes $(13,14)$. Moreover, Schültz et al. (12) have reported a stimulatory adenosine receptor $\left(A_{2}\right.$ or $\left.R a\right)$ coupled to the adenylate cyclase system in rat liver plasma membranes. In the
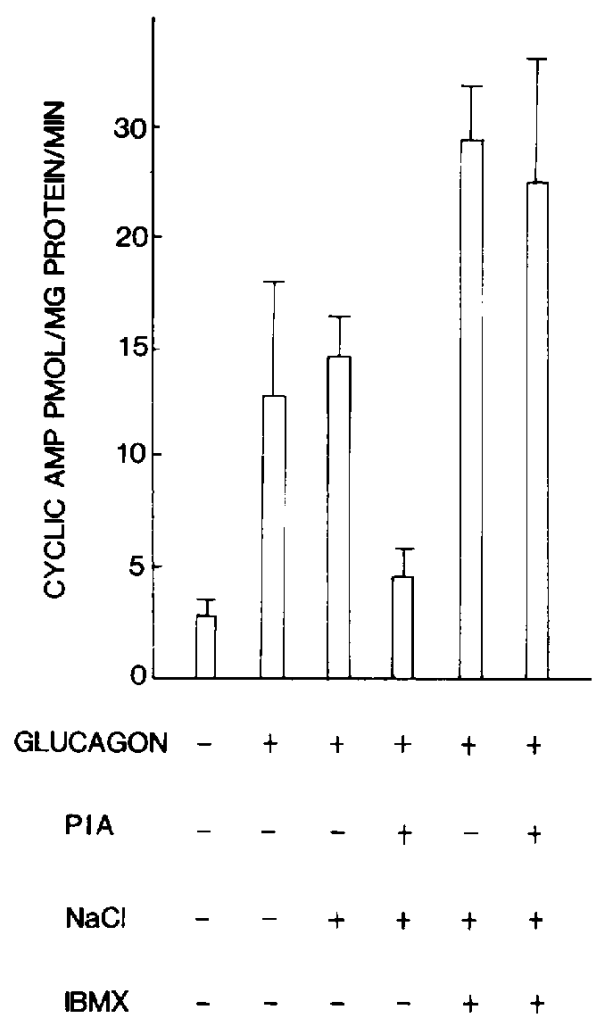

Fig. 7. Antagonism of $N^{6}$ phenylisopropyl-adenosine (PIA) induced inhibition on glucagonstimulated adenylate cyclase activity by 3-methyl-1isobutylxanthine (IBMX). Hepatic membranes were incubated with or without $10 \mathrm{nM}$ glucagon, $0.1 \mu \mathrm{M}$ PIA, $200 \mathrm{mM} \mathrm{NaCl}$ and $0.1 \mathrm{mM}$ IBMX, respectively. Data shown represent the mean \pm S.E. of four incubations.

present experiment, PIA, an analogue of adenosine previously shown to be a specific $\mathrm{R}$-site agonist at adenosine receptors (1, 25. 26) of the adenylate cyclase system was observed to stimulate the enzyme at concentrations above the micromolar range, suggesting the presence of the stimulatory adenosine receptor $\left(A_{2}\right.$ or $\left.R a\right)$ in rat hepatic membranes.

On the other hand, the present experiment has shown the dose-dependent attenuation by PIA of the glucagon-stimulated adenylate cyclase activity. Londos and Preston (10) have reported that there was no inhibition of the glucagon-stimulated enzyme by adenosine analogues related to a specific $R$ site agonist. Attention, however, must be paid to 
their experimental conditions in which the adenylate cyclase activity has been assayed in the presence of $\operatorname{Gpp}(\mathrm{NH}) \mathrm{p}$, a guanine nucleotide with exclusive stimulating action. In the adipocyte adenylate cyclase system, the adenosine receptor-mediated inhibition of the enzyme was observed to be absolutely dependent on GTP and amplified by sodium ions $(27-29)$. In the present experiment, the inhibition of the glucagon-stimulated adenylate cyclase activity by PIA was apparent in the presence of a low concentration (1.0 $\iota \mathrm{M})$ of GTP and sodium chloride. An interaction of the monovalent cation with the guanine nucleotide-binding regulatory component, revealing hormone-induced inhibition or impairing hormone-induced stimulation has been suggested (27-29). The inhibitory effect of PIA was antagonized by IBMX, which is selective for extracellular $R$ site receptors. These results suggest a receptor-mediated inhibitory system (25, 30 . 31) for adenosine on the hepatic membrane. A higher affinity for PIA inhibiting the glucagon-stimulated activity in the nanomolar range can be compared with the far greater values $(10 \mu \mathrm{M})$ for adenosine $(10,11,22-$ 24). The $\mid C 50$ value for $P \mid A(10 \mathrm{nM})$ is also compatible with those $(10$ to $100 \mathrm{nM})$ in the brain (32,33), fat cells $(3,34)$, heart (35) and adrenocortical cells (9). The inhibition by PIA fortified with sodium chloride was observed in the oresence GTP in the micromolar range. indicating the effect of the guanine nucleotide inhibitory system ( $\mathrm{Ni}$ ) linked to the enzyme.

The inhibitory effects of the glucagonstimulated enzyme activity by PIA disappeared and reversed into a stimulatory phase with increasing concentrations of GTP (more than $10 \mu \mathrm{M})$, suggesting the presence of a stimulatory (Ns) and an inhibitory ( $\mathrm{Ni}$ ) guanine nucleotide system of the enzyme in the action of PIA. The concentrations of the nucleoside required to produce a receptor-mediated inhibitory effect on the glucagon-stimulated adenylate cyclase were less than the micromolar range and of physiological significance, considering the fact that the circulating plasma levels of adenosine have been reported to be less than $2 \mu \mathrm{M}(36)$.

The present experiments suggest that adenosine in the micromolar range has dual effects on the hepatic adenylate cyclase system through the stimulatory receptor ( $R a$ or $A_{2}$ ) and the inhibitory receptor ( $R$ i or $A_{1}$ ). depending on the cellular concentrations of GTP and/or sodium chloride.

\section{References}

1 Fain, J.N. and Malbon, C.C.: Regulation of adenylate cyclase by adenosine. Mol. Cell. Biochem. 25, 143-169 (1979)

2 Van Calker, D., Muller, M. and Hamprecht, B.: Adenosine regulates via two distinct types of receptors, the accumulation of cyclic AMP in culture brain cells. J. Neurochem. 33, 999-1005 (1979)

3 Londos, C., Cooper, D.M.F. and Wolff, J.: Subclasses of external adenosine receptors. Proc. Natl. Acad. Sci. U.S.A. 77, 2551-2554 (1980)

4 Wolff, J., Londos, C. and Cooper, D.M.F.: Adenosine receptor and the regulation of adenylate cyclase. Adv. Cyclic Nucleotide Res. 14, 199-214 (1981)

5 Kowal, J, and Fiedler, R.P.: Adrenal cells in tissue culture II: Steroidogenic response to nucleosides and nucleotides. Endocrinology 84, 1113-1117 (1969)

6 Wolff, J. and Cook, G.H.: Activation of steroidogenesis and adenylate cyclase by adenosine in adrenal and Leydig tumor cells. J. Biol. Chem. 252, 687-693 (1977)

7 Peck, W.A., Carpenter, J.G. and Schuster, R.J.: Adenosine-mediated stimulation of bovine cell adenylate cyclase activity. Endocrinology 99, 901-909 (1976)

8 Glynn, P. and Cooper, D.M.F.: Inhibition of bovine adrenocortical adenylate cyclase activity by adenosine. Biochim. Biophys. Acta 526, 605-621 (1978)

9 Shima, S.: Inhibition by adenosine of ACTHstimulated adenylate cyclase and steroidogenesis in the adrenal cortex. Mol. Cell. Endocrinol. 47. 35-42 (1986)

10 Londos, C. and Preston, M.S.: Regulation of glucagon and divalent cations of inhibition of hepatic adenylate cyclase by adenosine. J. Biol. Chem. 252, 5951-5956 (1977)

11 Londos, C. and Wolff, J.: Two distinct adenosine-sensitive sites on adenylate cyclase. Proc. Natl. Acad. Sci. U.S.A. 74, 5482-5486 (1977)

12 Schültz, W., Tuisi, E. and Kraupp, O.: Adenosine receptor agonists: Binding and adenylate cyclase stimulation in rat liver plasma membranes. 
Naunyn Schmiedebergs Arch. Pharmacol. 319, 34-39 (1982)

13 Hoffer, L.J. and Lowenstein, J.M.: Effects of adenosine and adenosine analogues on glycogen metabolism in isolated rat hepatocytes. Biochem. Pharmacol. 35, 4529-4536 (1986)

14 Bartrons, R., Van Schaftingen, E. and Hers, H.G.: The ability of adenosine to decrease the concentration of fructose 2,6-bisphosphate in isolated hepatocytes. Biochem. J. 218, 157163 (1984)

15 Neville, D.M.: Isolation of an organ specific protein antigen from cell-surface membranes of rat liver. Biochim. Biophys. Acta. 313, 338349 (1968)

16 Lowry, O.H., Rosebrough, N., Farr, A.L. and Randall, R.J.: Protein measurement with the Folin phenol reagent. J. Biol. Chem. 193, 265275 (1951)

17 Shima, S., Kawashima, Y., Hirai, M., Asakura, M. and Kouyama, H.: Studies on cyclic nucleotides in the adrenal gland. Endocrinology 106, 948951 (1980)

18 Shima, S., Komoriyama, K., Hirai, M. and Kouyama, H.: Blockade of heterologous desensitization of prostate adenylate cyclase. J. Biol. Chem. 258, 2083-2086 (1983)

19 Shima, S., Okeyama, N., Oikawa, S. and Akamatu, N.: Effects of chronic propranolol treatment on hepatic adenylate cyclase system in the rat. J. Toxicol. Sci. 12, 309-319 (1987)

20 Gilman, A.G.: A protein binding assay for cyclic AMP. Proc. Natl. Acad. Sci. U.S.A. 67, 305$312(1970)$

21 Moriwaki, K. and Foa, P.P.: Inhibition of rat liver adenylate cyclase by adenosine and adenine nucleotides. Experimentia 26, 22-23 (1970)

22 Johnson, R.A. and Welden, J.: Characteristics of the enzymatic hydrolysis of $5^{\circ}$-adenylylimidodiphosphate: Implications for the study of adenylate cyclase. Arch. Biochem. Biophys. 183, 216-227 (1977)

23 McKenzie, S.G. and Bar, H.P.: On the mechanism of adenylate cyclase inhibition by adenosine. Can. J. Physiol. Pharmacol. 51, 190-196 (1973)

24 Londos, C., Cooper, D.M.F., Scoegel, W. and Rodbell, M.: Adenosine analogs inhibit adipocyte adenylate cyclase by a GTP-dependent process: Basis for actions of adenosine and methylxanthine on cyclic AMP production and lipolysis. Proc. Natl. Acad. Sci. U.S.A. 75, 5362-5366
(1978)

25 Trost, T. and Schwabe, U.: Adenosine receptors in fat cells. Identification by ${ }^{3} \mathrm{H}-\mathrm{N}^{8}$-phenylisopropyladenosine binding. Mol. Pharmacol. 19, 228-235 (1981)

26 Cooper, D.M.F., Schlegel, W., Lin, M.C. and Rodbell, M.: The fat cell adenylate cyclase system. J. Biol. Chem. 254, 8927-8931 (1979)

27 Aktories, K, Schulz, G. and Jacobs, K.H.: Regulation of adenylate cyclase activity in hamster adipocytes. Naunyn Schmiedebergs Arch. Pharmacol. 312, 167-173 (1980)

28 Aktories, K., Schultz, G. and Jakobs, K.H.: Na amplifies adenosine receptor-mediated inhibition of adipocytes adenylate cyclase. Eur. J. Pharmacol. 71, 157-160 (1981)

29 Aktories, K., Schultz, G. and Jacobs, K.H.: The hamster adipocyte adenylate cyclase system. Biochim. Biophys. Acta 676, 59-67 (1981)

30 Steer, M.L. and Wood, A.: Regulation of human platelet adenylate cyclase by epinephrine. prostaglandin $E_{1}$ and guanine nucleotides. J. Biol. Chem. 254, 10791-10797 (1979)

31 Woodcock, E.A., Johnson, C.I. and Olsson, C.A.: Alpha-adrenergic inhibition of renal control and adenylate cyclase. J. Cyclic Nucleotide Res. 6, 261-270 (1980)

32 Cooper, D.M., Londos, C. and Rodbell, M.: Adenosine receptor-mediated inhibition of rat cerebral corticat adenylate cyclase by a GTPdependent process. Mol. Pharmacol. 18, 598601 (1980)

33 Daly, J.W., Bruns, R.F. and Snyder, S.H.: Adenosine receptors in the central nervous system: relationship to the central actions of methylxanthins. Life Sci. 28, 2083-2097 (1981)

34 Londos, C., Wolf, J. and Cooper, D.M.F.: Action of adenosine on adenylate cyclase. In Physiological and Regulatory Functions of Adenosine and Adenine Nucleotides, Edited by Baer. H.P. and Drummond, G.I., p. 271-281. Raven Press, New York (1979)

35 Leung, E., Johnson, C.I. and Woodcock, E.A.: Demonstration of adenylate cyclase coupled adenosine receptors in guinea pig venticular membranes. Biochem. Biophys. Res. Commun. 110, 208-215 (1983)

36 Arch, J.R.S. and Newsholm, E.A.: The control of the metabolism and hormonal role of adenosine. Essays Biochem. 14, 82-123 (1978) 